\title{
Examination of Turkish Middle School Students' National Belonging Levels in Terms of Different Variables
}

\author{
Nihal Baloğlu Uğurlu* \\ Turkish and Social Sciences Department, Faculty of Education, Nigde Omer Halisdemir \\ University, Nigde, Turkey \\ ORCID: 0000-0002-2097-9434
}

\begin{tabular}{ll}
\hline \hline Article history & The purpose of this study was to determine middle school students' \\
Received: & national belonging levels in terms of different variables. In this \\
& quantitative study, middle school students' views on national belonging \\
Received in revised form: & were determined by the "National Belonging Scale for Middle School \\
15.06 .2021 & Students". The study was conducted with 1318 middle school students in \\
& Niğde province of Turkey during the Spring term of the 2019-2020 \\
Accepted: & academic year. Research data were collected through "National \\
12.07 .2021 & Belonging Scale for Middle School Students" and were analysed with \\
& SPSS 24 software package. According to the study results, middle school \\
Key words: & students had a high positive view of their national belonging. Their \\
\hline National belonging, & gender did not make a statistical difference in terms of both reasons and \\
Social Studies, & results of their national belonging. On the other hand, students' views on \\
Middle school students. & national belonging differed in terms of their grade level. Again, although \\
& there was no difference between the public and private schools in terms \\
& of reasons of their national belonging, there was a statistically significant \\
& difference between them in terms of the results of their national \\
& belonging in favor of the public school. Another difference was \\
determined between Turkish and refugee students' national belonging. & \\
& Turkish students' mean scores of reasons and results of their national \\
& belonging were statistically higher than the refugee students' mean \\
& scores. Considering national belonging in terms of each variable, middle \\
& school students' national belonging can be strengthened with some \\
& activities that can be done within the scope of the implicit program as \\
& well as the educational activities carried out within the curriculum at \\
schools. Social Studies is the most important course into which works on \\
this subject can be integrated.
\end{tabular}

\section{Introduction}

Every individual has a sense of belonging. The individual can develop his/her sense of belonging for certain groups (e.g. family) without any choice in the matter. Based on his/her personal preferences, the individual can also develop his/her sense of belonging for certain groups with which he/she has social and cultural interactions and toward whom feels trust and loyalty. However, it would be beneficial to discuss the social relationships the individual

\footnotetext{
*Correspondency: nihalugurlu@ohu.edu.tr
} 
develops based on the causality of his/her belonging on a micro-scale if his/her belonging is for certain small groups or on a macro-scale if his/her belonging is for society (Alptekin, 2011). As a matter of fact, the qualitative characteristics of the group determine the level of belonging of the individual and the belonging to be realized becomes more than a feeling for individuals, living together, sharing time and effort (Mavili, Kesen \& Daşbaş, 2014), and it is certain that the way individuals show these meaningful behaviors will differ depending on the groups they belong to. However, the individual's sense of coexistence requires that he/she first recognizes they/them own existence and strengthen his/her own personality. The better an individual knows himself/herself and becomes aware of his/her characteristics, the more self-confident he/she becomes and he/she communicates effectively and positively with his/her environment. Thus, there is a direct correlation between an individual's social identity characteristics and belonging. Thereupon, it is not possible to address the problem of belonging without integrating these two concepts (Çağırkan, 2019).

\section{Identity and Belonging}

There is no doubt that the sense of national belonging overlaps with the concept of social identity. Social identity acquisition is the behavioral process that an individual cannot develop alone and performs "with others" or "against others" as a result of certain interactions in the social environment (Güleç, 2002). In this sense, the questions of "Who are you?" or "Who am I?" are important ones the individual asks throughout his/her life (Atak, 2011; Vignoles, 2018). The personal characteristics are also the answers to these questions and the way(s) the individual is introduced to the society or recognized by the society are a reflection of his/her identity. An individual's identity is also an indicator of how he/she differs from others (Şimşek, 2002). As a matter of fact, while the borders of Turkish identity were drawn in the teaching of history subjects of our own country, the discourse of the "other" was also needed, and in this context, the impact of internal and external enemies on the formation of national identity and unity-togetherness was discussed (Yıldırım, 2014). The fact that the individual integrates different identity characteristics (gender, ancestry, profession, religion, hobby, and others) into his/her own personality makes his/her life story unique (Owens, Robinson, \& Lovin, 2010).

The concepts of identity and belonging are two integrated concepts. When describing an individual, his/her personal characteristics are also about his/her belonging to a group. The individual defines his/her ethnic identity by taking other people of that ethnic origin as a reference to himself/herself, or having the common spirit of other individuals belonging to his/her profession, or involving himself/herself in the organization formed by people who share the same political view because the individual has a sense of belonging. Considering this situation from another point of view, as Göker (2015) stated, when the individual defines himself/herself with his/her identity characteristics, he/she refers to "who he/she is not" in a way. When an individual says "I am from Erzurum", for instance, people may understand this as he/she does not accept people from İzmir as a fellow townsman, and when an individual says "I am a teacher", people may understand he/she does not belong to a law bar.

Usually, another place or another group to which an individual does not belong is ostracized by him/her and means a lack of a sense of belonging. However, the aforementioned integration or lack of identity and belonging are situations that can be considered for local societies and on a small scale. The situation is different for a large scale of mobility and change, in other words, for people who migrate to another country. For them, the concepts of identity and belonging gain a wider and even universal significance. The identity mentioned 
in this format is an identity characteristic that is defined as "national identity" rather than the "social identity" mentioned earlier and is integrated with a set of values and behaviors imposed on the individual by the society he/she is born and raised in. In this way, the identity acquisitions of individuals who migrate to a different country and live in the society of that country can be evaluated in three ways. The first of these is the individual achieving social integration by both maintaining his/her own national identity characteristics and adapting certain values of the host society (Madsen \& Naerssen, 2003). The second is the loss/destruction of the individual's own national identity within the host society (Göker, 2015). The third is the individual's ostracizing others while trying to maintain his/her own national identity within the host society, or the tendency to be denied and ostracized by others (Sözer, 2019). Referred to also as an identity problem, this last dimension is the most difficult one in terms of social integration. While it is difficult for an individual to abandon some life habits and material and spiritual values that he/she adopted and identified with himself/herself, it is not easy for an individual to live in a different geography and society with different cultural characteristics without hesitation (Özyurt, 2012). As a matter of fact, past experiences are also important in the individual's belonging, and an individual or group, place of residence (space), a certain period of time, or another piece of identity can affect belonging (Hatcher \& Stubbersfield, 2013). In addition, the way an individual who has to live in another country is perceived by the people of that society - and especially if the perception and labeling of the members of the host society contradict with how the individual defines himself/herself - may also emerge as an identity problem (Du Bois 1994 \& Howard 2000 \& Kumsa 2006 cited in Kebede, 2010). In the end, in most societies, the most important problem for the immigrants is the ethnic discrimination they face in addition to their basic care needs' not being met (Erbaş, 2008). This tends to weaken their ties to the society in which they live in.

National belonging is a feeling of individuals who consider themselves a part of the society, feel valuable for that society, and thus identify their happiness and achievement with the society they live in (Adler, 1964 cited in Duru, 2015). Therefore, every parent wants their own child to have this feeling. This is true for every teacher and his/her students, every employer and his/her employees, and every state and its citizens as well. Although sense of belonging is a life-long acquisition of life experiences, this concept is very important for the young generation who are included in the formal education process starting from pre-school. As a matter of fact, in the decisions taken during the $18^{\text {th }}$ National Education Council held between 1-5 November 2010, emphasis was placed on strengthening common cultural values by referring to the importance of belonging (MEV (Turkish National Education Foundation, 2014).

\section{Is belonging taught?}

Education has a great role in the development of individuals' belonging to the society and state they live in. The education of the individual starts in the family and continues in school. The difference between the education in the school and the education in the family is that educational activities are carried out systematically with an explicit and implicit curriculum in schools. The social relationships that the student establishes with his/her friends and teachers in the school environment are quite functional in preparing him/her for social life. Behaviors that are undesirable to be displayed in the school environment such as the feeling of loneliness stemming from not feeling belonging to the school community, which is a small part of the social institution, tension and hostility between peers, and disciplinary problems may arise as a result of the lack of a sense of belonging (Finn, $1989 \&$ Scanlon, 
Rowling \& Weber, 2007 \& Voelkl, 1997 as cited in Gizir, 2019). On the other hand, factors such as the support given by the teacher to the student, harmonious friendships, high academic achievement, functionality of discipline rules, and participation in extracurricular activities increase students' level of commitment to their school and contribute positively to their belonging to social life (Allen \& Bowles, 2012). In addition, the realization of students' developing a sense of belonging to social life is possible with the systematic teaching of the subject areas. Social Studies is the most important course in this respect. This course aims to transfer certain material and spiritual values of society to students. Compared to other courses, this necessitates Social Studies to undertake more responsibilities about students' adjustment to society. It may be important to see the relationship between students' acquisition of belonging and Social Studies in this study. It is possible to associate the reasons and results of students' national belonging with the social and political environment they live in, and the acquisition and awareness they acquire in Social Studies. Therefore, the present study aimed to assess middle school students' national belonging in terms of different variables. In line with this purpose, the answers to the following questions were sought:

(1) What are the political and socio-cultural reasons and the results of middle school students' national belonging?

(2) Do the political and socio-cultural reasons and results of middle school students' national belonging change according to their gender, class level, school type, and legal status?

(3) What are the prediction levels of the study variables and the reasons and results of middle school students' national belonging?

\section{Method}

This study employed the quantitative research approach. This method was preferred in order to determine middle school students' views on national belonging with the items included in the study scale.

In the study, the general survey design aims to reach a general judgment about the universe. In order to determine the predictive level of the study variables on the results of middle school students' national belonging, the relational survey design was used. Relational survey design is a research design applied to reveal the existence or degree of change between more than one variable. In this design, the distinctions between certain situations are determined. As a matter of fact, the relationships determined by this design give some clues regarding the cause-effect relationship rather than forming precise judgments about it. Thus, what is known about a variable enables the researcher to make predictions about the unknowns about the variable on the other side (Karasar, 1999).

\section{Study Group}

This study was carried out with a total of 1318 students from every grade level of six public middle schools and one private middle school. The demographic characteristics of the participants are presented in Table 1. 
Table 1. Demographic characteristics of the participants

\begin{tabular}{llll}
\hline & & $\begin{array}{l}\text { Frequency } \\
\text { (f) }\end{array}$ & $\begin{array}{l}\text { Percentage } \\
(\boldsymbol{\%})\end{array}$ \\
\hline \multirow{2}{*}{ Gender } & Female & 687 & 52 \\
& Male & 631 & 48 \\
\hline \multirow{3}{*}{ Grade Level } & $5^{\text {th }}$ Grade & 291 & 22 \\
& $6^{\text {th }}$ Grade & 388 & 29 \\
& $7^{\text {th }}$ Grade & 302 & 23 \\
\multirow{2}{*}{ School Type } & $8^{\text {th }}$ Grade & 337 & 26 \\
\hline \multirow{2}{*}{ Legal Status } & Public School & 1172 & 89 \\
& Privative School & 146 & 11 \\
\hline & Turkish Citizen & 1158 & 88 \\
& Refugee & 160 & 12 \\
\hline
\end{tabular}

As can be understood from Table 1, 687 (52\%) of the participants were female, and 631 $(48 \%)$ were male. $291(22 \%)$ of the students in the study group were $5^{\text {th }}$ grade students, 388 $(29 \%)$ were $6^{\text {th }}$ grade students, $302(23 \%)$ were $7^{\text {th }}$ grade, and $337(26 \%)$ were $8^{\text {th }}$ grade students. $1172(89 \%)$ of the participating students attended public schools, and $146(11 \%)$ of them attended the private school. Finally, $1158(88 \%)$ of the participants were Turkish citizens, whereas $160(12 \%)$ of them were refugees.

\section{Data Collection Tools}

In the study, the "National Belonging Scale for Middle School Students" was developed by the researcher to obtain the quantitative data of the study. The development process of the study scale was carried out as follows:

\section{Writing of the Scale Items and Development of the Item Pool}

During the development of the item pool, the researcher first conducted a literature review and recorded some statements from the literature that could be used as scale items. In the next step, a total of 123 students from every grade level of a public school were asked the question of "Do you feel a belonging to this society? Can you elaborate on your answer?". In line with student answers to this single survey question, the item pool was expanded. In the next stage, individual and face-to-face interviews were made with a student from each grade level in parallel with the same question, and further contributions were made to the development of the statements in the item pool. There were 102 statements in the item pool in its last version. The researcher arranged these statements and eliminated 63 items, which she believed were similar in content, did not serve the study purpose, or could not be understood/answered, and then turned the pool into a 39-item scale. 24 of the items in this scale were about the reasons of belonging (political and socio-cultural), and 15 of them were about the consequences of belonging. The scale was developed as a three-point Likert type since it was believed that middle school students would express their decisions about their belonging better due to their developmental level. The final form of the scale was assessed by two field experts and one measurement expert. Experts recommended that one item in the reasons of belonging sub-dimension and two items in the results of belonging sub-dimension should be revised, and two items in the reasons of belonging sub-dimension and one item in the results of belonging sub-dimension should be removed from the scale. The researcher revised the scale in line with the recommendations. So, the pilot application was carried out on two different groups. The data obtained from the first group were used for the reliability study of the scale. The reliability study and the EFA study were carried out with 331 students. The CFA study was conducted with 1318 students. 


\section{Reliability and Validity Works of the Scale}

For the reliability of the scale, Cronbach's alpha coefficient and item-total correlation were calculated. Accordingly, the findings are as follows:

\section{Reliability}

Item-total correlation: Providing evidence for the validity of the items, item-total correlation explains the relationship between the scale item scores and the overall assessment score. The items with values 0.30 and above indicate very good discrimination. The items with values between 0.20 and 0.30 mean that the items can be included in the test if deemed necessary or that they need to be corrected. The items with values below 0.20 indicate that they should not be included in the test (Büyüköztürk, 2010). Item-total correlations of the items in the pilot scale are given in Table 2.

Table 2. Item-total correlations of the items in the pilot scale

\begin{tabular}{llll}
\hline & $\begin{array}{c}\text { Reasons for Belonging } \\
\text { Politic reasons }\end{array}$ & Socio-cultural reasons & Results of Belonging \\
\hline item1 &, 347 & & \\
item2 &, 207 & & \\
item3 &, 426 & & \\
item5 &, 526 & & \\
item8 &, 240 & & \\
item9 &, 551 & & \\
item13 &, 229 & & \\
item16 &, 369 & & \\
item17 &, 641 & & \\
item18 &, 243 &, 383 & \\
item19 &, 630 &, 413 & \\
item21 &, 681 &, 454 & \\
item22 &, 518 &, 473 & \\
item4 & &, 535 &, 139 \\
item6 & &, 463 &, 371 \\
item7 & & & \\
item10 & &, 406 &, 436 \\
item11 & & &, 405 \\
item12 & & &, 505 \\
item14 & & &, 261 \\
item15 & & & \\
item20 & & & \\
item23 & & & \\
item24 & & & \\
item25 & & & \\
item26 & & & \\
item27 & & & \\
item28 & & & \\
item29 & & & \\
item30 & & & \\
item31 & & & \\
item32 & & & \\
item33 & & & \\
\hline
\end{tabular}


In the pilot scale, there were 14 items in the political reasons of national belonging dimension with item-total correlations between 0.207 and $0.681,10$ items in the socio-cultural reasons of national belonging dimension with item-total correlations between 0.251 and 0.535 , and 15 items in the results of national belonging dimension with item-total correlations between 0.139 and 0.521 (Table 2). Item 32 with an item-total correlation below 0.20 and items 2, 8, $13,15,18$, and 30 with an item-total correlation between 0.20 and 0.30 were excluded from the test. Item 28 was corrected and included in the test.

Cronbach's alpha coefficient: Cronbach's alpha reliability coefficient is performed to determine the internal consistency in scales where Likert-like rating method is used (Seçer, 2018). The results of the Cronbach's alpha reliability analysis conducted in this scale showed that the reliability coefficient was 0.78 for the political reasons of national belonging dimension, 0.74 for the socio-cultural of national belonging dimension, and 0.71 for the results of belonging dimension. In scale studies, there is a widespread acceptance that the Cronbach's alpha value should be at least .70 and above (Büyüköztürk, 2010; Landis \& Koch, 1977 \& Robinson, Shaver, \& Wrightsman, 1991 cited in Seçer, 2018).

\section{Validity}

\section{Construct validity:}

In order to provide evidence for the construct validity of the scales, first, Exploratory Factor Analysis (EFA) was performed with the data from the first group. The factor loadings and explanation percentages obtained as a result of EFA are presented in Table 3.

Table 3. Factor loadings and explanation percentages obtained as a result of EFA

\begin{tabular}{|c|c|c|c|}
\hline & \multicolumn{2}{|c|}{ Reasons for Belonging } & \multirow{2}{*}{ Result of Belonging } \\
\hline & Politic reasons & Socio-cultural reasons & \\
\hline item21 & ,779 & & \\
\hline item19 &, 727 & & \\
\hline item17 &, 724 & & \\
\hline item9 & ,685 & & \\
\hline item22 & 660 & & \\
\hline item5 & ,652 & & \\
\hline item3 &, 541 & & \\
\hline item 16 & ,458 & & \\
\hline item1 & ,443 & & \\
\hline item11 & & 687 & \\
\hline item10 & & 660 & \\
\hline item 12 & & 642 & \\
\hline item7 & & ,629 & \\
\hline item6 & & ,596 & \\
\hline item4 & &, 521 & \\
\hline item14 & &, 507 & \\
\hline item20 & & ,338 & \\
\hline item27 & & &, 720 \\
\hline item 25 & & & ,689 \\
\hline item 23 & & & ,608 \\
\hline item33 & & &, 583 \\
\hline item31 & & & ,566 \\
\hline item24 & & & 551 \\
\hline item26 & & &, 521 \\
\hline item 29 & & & 520 \\
\hline item 28 & & & 426 \\
\hline \multirow{2}{*}{$\%$ of variance } & 30.669 & 12.402 & \multirow{2}{*}{33.884} \\
\hline & & & \\
\hline
\end{tabular}


According to the EFA results, the scale had two sub-dimensions and the factor loadings of the items in the first sub-dimension ranged from 0.443 to 0.779 , and factor loadings of the items in the second sub-dimension ranged from .338 to 0.687 . The factor loadings of the items in the second scale varied between 0.426 and 0.720 (Table 3).

Confirmatory factor analysis

After the items were corrected, 29 items, two of which were control items, were administered to 1318 students for the second time. Confirmatory factor analysis (CFA) was performed to determine the construct validity of the scales. The goodness of fit values obtained as a result of CFA are presented in Table 4.

Table 4. Goodness of fit values for the National Belonging Scale for Middle School Students

\begin{tabular}{lllllllllll}
\hline$\chi 2$ & Sd & $\mathbf{p}$ & $\chi \mathbf{2} / \mathbf{s d}$ & RMSEA & NFI & NNFI & CFI & GFI & AGFI & IFI \\
\hline 1046.09 & 257 & $\mathrm{p}<.05$ & 4.07 & 0.048 & 0.95 & 0.96 & 0.97 & .94 & 0.92 & 0.97 \\
\hline
\end{tabular}

The most frequently used statistics regarding model data fit with CFA are Chi-square $\left(\chi^{2}\right)$, $\chi 2 / s d$, RMSEA, NNFI, NFI, CFI, IFI, GFI, and AGFI. The calculated ratio of $\chi 2 / s d$ being less than two, the RMSEA value being lower than 0.05, the NFI and GFI values being higher than 0.95, the NNFI, CFI and IFI values being higher than 0.97, and the AGFI value being higher than 0.90 indicate that there is good fit between the model and the data. The calculated ratio of $\chi^{2}$ /sd being lower than three, the RMSEA value being lower than 0.10 , the GFI and NFI values being higher than 0.90 , the AGFI value being higher than 0.85 , and the NNFI, CFI and IFI values being higher than 0.95 are the acceptable lower limits for model data fit (Yilmaz \& Çelik, 2009).

According to the CFA results, for the first scale, the $\chi 2$ sd was 7.68 , the AGFI value was 0.93 , the GFI value was 0.95 , RMSEA value was 0.071 , NFI value was 0.94 , NNFI value was 0.93 , and CFI and IFI values were 0.95. As seen in Table 4, the AGFI and GFI goodness of fit values had a good model fit, while the other values had a reasonable fit. According to the CFA results, for the first scale, the $\chi 2$ sd was 6.44 , the AGFI value was 0.95 , the GFI value was 0.97 , the RMSEA value was 0.064, the NFI and NNFI value was 0.97, and the CFI and IFI values were 0.98 . As seen in Table 4 , all the values except the RMSEA value had a good model fit. The $\chi 2 / \mathrm{sd}$ ratio calculated for both models poor model fit. Considering all the values related to model goodness of fit, it is seen that the established models fit well with the data. These findings revealed that the factor structure of the Reasons of Belonging Scale and the Result of Belonging Scale was confirmed in the data obtained from another study group, and therefore the scales had structural validity.

\section{Data Collection Techniques}

In the study, the purposeful sampling method was employed while determining the study participants. In purposeful sampling method, one or more situations are required to have certain characteristics while obtaining healthy data in accordance with the study purpose (Koç Başaran, 2017). In this study, the most important reason for choosing purposeful sampling method was to reach a study group within the scope of the school type and legal status variables of the study. In order to realize this purpose, the study was carried out with middle school students from one private school and seven different public schools that had the highest number of refugee students affiliated with Niğde Provincial Directorate of National Education. Schools with the highest number of refugee students were also preferred due to the awareness the students would have because of the existence of Turkish and refugee students' 
communication and interactions in these schools and the pre-acceptance that the reflection of this situation on their belonging may be at a higher level.

At the beginning of the data collection process, an application was made to the schools after obtaining the necessary official permissions. Then, when the school administration deemed it appropriate, the researcher went to the students' classrooms and asked them to fill in the scale after making sure there were no questions about the scale items on students' minds. During the data collection process, 1686 people were reached, and 328 papers were eliminated during data entry, taking the control item in the scale into consideration. Another important factor to consider during data collection was the data obtained from the refugee students. The interviews showed that these students did not know their legal status exactly. In the interviews with the school administration and a few parents who were reached, these students were considered conditional refugees and fit the following definition:

A conditional refugee is a person who as a result of events occurring outside European countries and owing to well-founded fear of being persecuted for reasons of race, religion, nationality, membership of a particular social group or political opinion, is outside the country of their nationality and is unable or, owing to such fear, is unwilling to avail himself/herself of the protection of that country; or who, not having a nationality and being outside the country of former habitual residence as a result of such events, is unable or, owing to such fear, is unwilling to return to it, shall be granted conditional refugee status upon completion of the refugee status determination process. Conditional refugees shall be allowed to reside in Turkey temporarily until they are resettled to a third country (YUKK (Turkish Foreigners and International Protection Law), 2021) .

For this reason, these students were generally described as "refugee students" in the study. In order for the scale items to be better understood by the refugee students, the refugee students were gathered by the researcher in an empty classroom, and after the items were translated to refugee students' native language by their peers who spoke the native language (Arabic and Persian) and who knew Turkish at a good level, they were asked to fill the scale. The only scale item that refugee students had difficulty in understanding was "having a sense of belonging to this society because of being born here". When the refugee students said "I wasn't born in this country", the researcher directed them by saying "If you were born in this country, would you feel more belonging to this country? Think about it".

\section{Data Analysis}

In the study, the interval to which the students' arithmetic means fell was calculated by using the interval width formula (Tekin, 1977) in order to determine middle school students' political and socio-cultural reasons and results of national belonging levels. The level intervals calculated with the formula are presented in Table 5.

Table 5. Arithmetic mean score intervals of the National Belonging Scale for Middle School Students

\begin{tabular}{ll}
\hline Level & Interval \\
\hline Low & $1.00-1.66$ \\
Medium & $1.67-2.33$ \\
High & $2.34-3.00$ \\
\hline
\end{tabular}

In the study, since the assumptions of normality and homogeneity of variances were met, independent samples t-test was used to measure the differences in middle school students' 
mean scores regarding the political and socio-cultural reasons and results of national belonging according to the variables of gender, school type, and legal status. In addition, oneway analysis of variance was used to measure the political and socio-cultural reasons and results of national belonging according to grade level.

Multivariate regression analysis' backward selection method was performed to analyse how much the study variables predicted the results of belonging. Before the analysis, whether the assumptions (outliers, normality, linearity, multicollinearity, and autocorrelation) were met was tested. First, whether there were outliers or not was examined. Whether there were univariate outliers or not was found by calculating the $\mathrm{z}$ standard scores, and 42 data that were not between -3 and +3 were removed from the analysis. Then, whether there were multivariate outliers was determined by calculating the Mahalanobis distances, and some data was removed from the analysis. Thus, the study was conducted with a total of 1311 data. In order to determine whether the normality assumption was met or not, the skewness and kurtosis values were examined. These values were between -1 and +1 . So, it was determined that the data did not show excessive deviation from normal distribution. To determine whether autocorrelation existed or not, the Durbin-Watson value was calculated, and this value was found as 1.851. Since the value found was between 1.5 and 2.5 , the autocorrelation assumption was met. Whether the relationship between multivariate normality and the predictor (independent) variables and the dependent variable was linear was examined with a scatter plot. It was revealed that there was a linear relationship between the variables other than the gender variable and the results of belonging, the dependent variable. Thus, the gender variable was not included in the analysis. To determine whether there was a multicollinearity problem, tolerance (1-R2) and VIF (variance inflation factor) values were calculated. Tolerance values were found greater than 0.20 and VIF values less than 10. It was determined that there was no multicollinearity between the predictor variables. Dummy variables were defined for each categorical variable (Table 6).

Table 6. Dummy variables regarding the categorical variables

\begin{tabular}{|c|c|c|c|c|}
\hline Variable & & Dummy variable & Coding & Excluded category \\
\hline \multirow{3}{*}{ Grade level } & $1.5^{\text {th }}$ & $5^{\text {th }}$ grade & 5:1 Others:0 & \multirow{3}{*}{$8^{\text {th }}$ grade } \\
\hline & 2. $6^{\text {th }}$ & $6^{\text {th }}$ grade & $6: 1$ Others:0 & \\
\hline & 3. $7^{\text {th }}$ & $7^{\text {th }}$ grade & $7: 1$ Others:0 & \\
\hline School & $\begin{array}{l}\text { 1: Public } \\
\text { 2: Private school }\end{array}$ & School-public & $\begin{array}{l}\text { 1: Public school, } \\
\text { 0: Private school }\end{array}$ & Private school \\
\hline Gender & $\begin{array}{l}\text { 1: Female } \\
\text { 2: Male }\end{array}$ & Gender-female & 1: Female, 0:Male & Male \\
\hline Country & $\begin{array}{l}\text { 1: Turkey } \\
\text { 2: Other }\end{array}$ & Country-Turkey & 1: TC, 0:Other & Other \\
\hline
\end{tabular}

SPSS 24 statistical program was used to analyze the data, and the significance level was accepted as $\mathrm{p}=0.05$.

\section{Findings}

In the study, the minimum and maximum values of the scores of middle school students' political and socio-cultural reasons of national belonging and results of national belonging, and the arithmetic mean and standard deviation values are presented in Table 7.

Table 7. Descriptive data on the study group's national belonging

\begin{tabular}{llllll}
\hline Sub-dimension & $\mathbf{N}$ & Min. & Max. & $\overline{\mathbf{x}}$ & $\mathbf{S}$ \\
\hline Political reason & 1318 & 1.25 & 3.00 & 2.43 & .413 \\
Socio-cultural reason & 1318 & 1.44 & 3.00 & 2.54 & .339 \\
Result of belonging & 1318 & 1.78 & 3.00 & 2.65 & .284 \\
\hline
\end{tabular}


The middle school students' scores of the political reasons of national belonging dimension varied between 1.25 and 3.00, and the arithmetic mean was 2.43 . The minimum value from the socio-cultural reason of national belonging dimension scores was 1.44 and the maximum value was 3.00, and the arithmetic mean was 2.54 . The minimum value from the results of national belonging dimension scores was 1.78 and the maximum value was 3.00. The arithmetic mean of the scores belonging to this dimension was 2.65. The arithmetic mean of the scores for all dimensions seen in this table is evidence that middle school students' national belonging is "high" in terms of political and socio-cultural reasons and results of belonging (Table 7).

Middle school students' reasons and results of belonging levels and their comparisons according to their gender are presented in Table 8.

Table 8. Middle school students' independent samples t-test results according to the gender variable

\begin{tabular}{|c|c|c|c|c|c|c|c|}
\hline Sub-dimension & Gender & $\mathbf{N}$ & $\overline{\mathbf{x}}$ & $\mathbf{S}$ & Sd & $\mathbf{t}$ & p \\
\hline \multirow{2}{*}{ Political reason } & $\mathrm{F}$ & 687 & 2.42 & .422 & \multirow{2}{*}{1313} & \multirow{2}{*}{-.292} & \multirow{2}{*}{.482} \\
\hline & $\mathrm{M}$ & 628 & 2.44 & .403 & & & \\
\hline \multirow{2}{*}{ Socio-cultural reason } & $\mathrm{F}$ & 687 & 2.54 & .342 & \multirow{2}{*}{1313} & \multirow{2}{*}{.007} & \multirow{2}{*}{.995} \\
\hline & $\mathrm{M}$ & 631 & 2.54 & .337 & & & \\
\hline \multirow{2}{*}{ Result of belonging } & $\mathrm{F}$ & 687 & 2.65 & .272 & \multirow{2}{*}{1313} & \multirow{2}{*}{-.414} & \multirow{2}{*}{.679} \\
\hline & $\mathrm{M}$ & 631 & 2.66 & .297 & & & \\
\hline
\end{tabular}

According to Table 8, female students' mean score of political reasons of national belonging was 2.42 , whereas male students' mean score was 2.44 . Also, the t-test result $\left(\mathrm{t}_{(1313)}=-\right.$. 292 ; $\mathrm{p}>.05)$ revealed that there was no difference between female and male students in terms of political reasons of national belonging. In terms of female and male students' socio-cultural reasons of national belonging, the mean score of both groups was 2.54. Thus, there was no significant difference after the $\mathrm{t}$-test $\left(\mathrm{t}_{(1316)}=.007 ; \mathrm{p}>.05\right)$. Female students' mean score of results of national belonging was 2.65, whereas male students' mean score was 2.66. Therefore, there was also no statistical difference $\left(\mathrm{t}_{(1313)}=-.414 ; \mathrm{p}>.05\right)$.

Table 9. One-way variance analysis results and descriptive statistics of the middle school students' mean scores of national belonging according to grade levels

\begin{tabular}{|c|c|c|c|c|c|c|c|c|c|c|c|}
\hline 3 & $\begin{array}{l}\text { Grade } \\
\text { Level } \\
\end{array}$ & $\overline{\mathbf{x}}$ & $\mathbf{S}$ & $\begin{array}{l}\text { Source of } \\
\text { variance }\end{array}$ & $\begin{array}{l}\text { Sum of } \\
\text { squares }\end{array}$ & sd & $\begin{array}{l}\text { Mean } \\
\text { Square }\end{array}$ & $\mathbf{F}$ & $\mathbf{p}$ & Sign. & $\begin{array}{l}\text { Eta- } \\
\text { squared }\end{array}$ \\
\hline \multirow{4}{*}{$\begin{array}{l}\text { Political } \\
\text { reason }\end{array}$} & $5^{\text {th }}$ grade & 2.58 & .360 & $\begin{array}{l}\text { Between } \\
\text { groups }\end{array}$ & 10.507 & 3 & 3.502 & \multirow{3}{*}{21.522} & \multirow{3}{*}{$.000 *$} & \multirow{3}{*}{$\begin{array}{l}5-6 \\
7,8 \\
6-7\end{array}$} & \multirow{3}{*}{0.033} \\
\hline & $\begin{array}{l}6^{\text {th }} \text { grade } \\
7^{\text {th }} \text { grade }\end{array}$ & $\begin{array}{l}2.45 \\
2.34\end{array}$ & $\begin{array}{l}.375 \\
.438\end{array}$ & $\begin{array}{l}\text { Within } \\
\text { Groups }\end{array}$ & 213.671 & 1313 & \multirow[t]{2}{*}{.163} & & & & \\
\hline & $8^{\text {th }}$ grade & 2.37 & .437 & Total & 224.179 & 1316 & & & & & \\
\hline & $5^{\text {th }}$ grade & 2.64 & .328 & $\begin{array}{l}\text { Between } \\
\text { groups }\end{array}$ & 3.662 & 3 & 1.221 & \multirow{3}{*}{10.842} & \multirow{3}{*}{$.000 *$} & \multirow{3}{*}{$\begin{array}{l}5-6 \\
7,8\end{array}$} & \multirow{3}{*}{0.024} \\
\hline \multirow{3}{*}{$\begin{array}{l}\text { Socio- } \\
\text { cultural } \\
\text { reason }\end{array}$} & $6^{\text {th }}$ grade & 2.53 & .339 & $\begin{array}{l}\text { Within } \\
\text { Groups }\end{array}$ & 147.831 & 1313 & \multirow[t]{2}{*}{.113} & & & & \\
\hline & $\begin{array}{l}7^{\text {th }} \text { grade } \\
8^{\text {th }} \text { grade }\end{array}$ & $\begin{array}{l}2.49 \\
2.53\end{array}$ & $\begin{array}{l}.337 \\
.336\end{array}$ & Total & 151.493 & 1316 & & & & & \\
\hline & $5^{\text {th }}$ grade & 2.70 & .273 & $\begin{array}{l}\text { Between } \\
\text { groups }\end{array}$ & 1.346 & 3 & .449 & \multirow{4}{*}{5.630} & \multirow{4}{*}{$.001 *$} & \multirow{4}{*}{$5-6,7$} & \multirow{4}{*}{0.013} \\
\hline \multirow[t]{3}{*}{$\begin{array}{l}\text { Result of } \\
\text { belonging }\end{array}$} & $6^{\text {th }}$ grade & 2.63 & .294 & $\begin{array}{l}\text { Within } \\
\text { Groups }\end{array}$ & 104.650 & 1313 & \multirow[t]{3}{*}{.080} & & & & \\
\hline & $7^{\text {th }}$ grade & 2.62 & .291 & \multirow{2}{*}{ Total } & \multirow{2}{*}{105.996} & \multirow{2}{*}{1316} & & & & & \\
\hline & $8^{\text {th }}$ grade & 2.67 & .268 & & & & & & & & \\
\hline
\end{tabular}

$* \mathrm{p}<0.05$ 
According to Table 9, middle school students' arithmetic mean scores of political and sociocultural reasons and results of national belonging significantly differ according to the grade level variable $(\mathrm{p}<0.05)$. The LSD multiple comparison test results revealed that the middle school students' arithmetic mean scores of political reasons of national belonging were 2.58 at the 5th grade, 2.45 at the 6th grade, 2.34 at the 7 th grade, and 2.37 at the 8 th grade. Between 5 th grade and the other grade levels, the significant difference was in favor of the 5th grade, whereas between the 6th and 7th grades, the significant difference was in favor of the 6th grade. The middle school students' arithmetic mean scores of socio-cultural reasons of national belonging were 2.64 at the 5th grade, 2.53 at the 6th grade, 2.49 at the 7 th grade, and 2.53 at the 8th grade. Thus, between 5th grade and other grade levels, the significant difference was in favor of the 5th grade. In addition, the middle school students' arithmetic mean scores of results of national belonging were 2.70 at the 5th grade, 2.63 at the 6th grade, 2.62 at the 7 th grade, and 2.67 at the 8th grade. Between the 5th grade, and 6th and 7th grades, the significant difference was in favor of the 5th grade. According to the eta-squared (n2) effect size values, the effect of the grade level variable on middle school students' political and socio-cultural reasons and results of national belonging was small.

Table 10. Independent samples t-test results of middle school students according to the school type

\begin{tabular}{|c|c|c|c|c|c|c|c|c|}
\hline Sub-dimension & School Type & $\mathbf{N}$ & $\overline{\mathbf{x}}$ & $\mathbf{S}$ & sd & $\mathbf{t}$ & $\mathbf{p}$ & $\begin{array}{l}\text { Eta- } \\
\text { squared }\end{array}$ \\
\hline \multirow[b]{2}{*}{ Political reason } & Public school & 1172 & 2.44 & .399 & \multirow[b]{2}{*}{1316} & \multirow[b]{2}{*}{2.012} & \multirow[b]{2}{*}{.046} & \multirow[b]{2}{*}{0.003} \\
\hline & $\begin{array}{l}\text { Private } \\
\text { school }\end{array}$ & 146 & 2.35 & .505 & & & & \\
\hline \multirow[b]{2}{*}{$\begin{array}{l}\text { Socio-cultural } \\
\text { reason }\end{array}$} & Public school & 1172 & 2.54 & .336 & \multirow[b]{2}{*}{1316} & \multirow[b]{2}{*}{.011} & \multirow[b]{2}{*}{.991} & \multirow[b]{2}{*}{-} \\
\hline & $\begin{array}{l}\text { Private } \\
\text { school }\end{array}$ & 146 & 2.54 & .365 & & & & \\
\hline \multirow[b]{2}{*}{$\begin{array}{l}\text { Result } \\
\text { belonging }\end{array}$} & Public school & 1172 & 2.66 & .282 & \multirow[b]{2}{*}{1316} & \multirow[b]{2}{*}{2.178} & \multirow[b]{2}{*}{$.030 *$} & \multirow[b]{2}{*}{0.005} \\
\hline & $\begin{array}{l}\text { Private } \\
\text { school }\end{array}$ & 146 & 2.60 & .292 & & & & \\
\hline
\end{tabular}

According to Table 10, middle school students' mean scores of political reasons of national belonging were 2.44 for public schools and 2.35 for the private school. In addition, the t-test results $\left(\mathrm{t}_{(1316)}=2.012 ; \mathrm{p}<.05\right)$ revealed that there was a significant difference between public and private school students in favor of the public school students in terms of political reasons of national belonging. On the other hand, in terms of public and private school students' socio-cultural reasons of national belonging, the mean score of both groups was 2.54. Therefore, there was no significant difference according to the $\mathrm{t}$-test $\left(\mathrm{t}_{(1316)}=.011 ; \mathrm{p}>.05\right)$. In terms of students' results of national belonging, public school students' mean score was 2.66, whereas private school students' mean score was 2.60. According to the t-test result $\left(\mathrm{t}_{(1316)}=2.178 ; \mathrm{p}<.05\right)$, a significant difference was determined between public and private school students in favor of the public school students in terms of results of national belonging. The eta-squared (n2) effect size value showed that middle school students' school type had a small effect on the results of their national belonging. 
Table 11. Independent samples t-test results of middle school students according to the legal status variable

\begin{tabular}{|c|c|c|c|c|c|c|c|c|}
\hline $\begin{array}{l}\text { Sub- } \\
\text { dimension }\end{array}$ & Legal Status & $\mathbf{N}$ & $\overline{\mathbf{x}}$ & $\mathbf{S}$ & Sd & $\mathbf{t}$ & $\mathbf{p}$ & $\begin{array}{l}\text { Eta- } \\
\text { squared }\end{array}$ \\
\hline \multirow[t]{2}{*}{ Political } & $\begin{array}{l}\text { Republic of } \\
\text { Turkey }\end{array}$ & 1158 & 2.45 & .421 & \multirow[t]{2}{*}{1316} & \multirow[t]{2}{*}{5.537} & \multirow[t]{2}{*}{$.000 *$} & \multirow[t]{2}{*}{0.022} \\
\hline & Other & 160 & 2.30 & .318 & & & & \\
\hline \multirow[t]{2}{*}{ Socio-cultural } & $\begin{array}{l}\text { Republic of } \\
\text { Turkey }\end{array}$ & 1158 & 2.56 & .339 & \multirow[t]{2}{*}{1316} & \multirow[t]{2}{*}{3.967} & \multirow[t]{2}{*}{$.000 *$} & \multirow[t]{2}{*}{0.012} \\
\hline & Other & 160 & 2.44 & .325 & & & & \\
\hline \multirow{2}{*}{$\begin{array}{l}\text { Result of } \\
\text { belonging }\end{array}$} & $\begin{array}{l}\text { Republic of } \\
\text { Turkey }\end{array}$ & 1158 & 2.67 & .275 & \multirow[t]{2}{*}{1316} & \multirow[t]{2}{*}{4.346} & \multirow[t]{2}{*}{$.000 *$} & \multirow[t]{2}{*}{0.014} \\
\hline & Other & 160 & 2.56 & .328 & & & & \\
\hline
\end{tabular}

According to Table 11, middle school students' mean scores of political reasons of national belonging were 2.45 for Turkish students and 2.30 for refugee students. The t-test results $\left(\mathrm{t}_{(1316)}=5.537 ; \mathrm{p}<.05\right)$ revealed that there was a significant difference between Turkish and refugee students in favor of the Turkish students in terms of political reasons of national belonging. Middle school students' mean scores of socio-cultural reasons of national belonging were 2.56 for Turkish students and 2.44 for refugee students. The t-test results $\left(t_{(1316)}=3.967 ; p<.05\right)$ put forth that there was a significant difference between the two groups in favor of the Turkish students. Furthermore, middle school students' mean scores of results of national belonging were 2.67 for Turkish students and 2.56 for refugee students. According to the t-test results $\left(\mathrm{t}_{(1316)}=4.346 ; \mathrm{p}<.05\right)$, there was a significant difference in favor of the Turkish students. The eta-squared ( 12 ) effect size value showed that middle school students' legal status had a small effect on the political and socio-cultural reasons and results of their national belonging.

The independent samples t-test results of Turkish and refugee students' political and sociocultural reasons and results of national belonging performed for each item in the scale are presented in Tables 12, 13, and 14.

Table 12. Independent samples t-test results of middle school students' political reasons of national belonging

\begin{tabular}{|c|c|c|c|c|c|c|c|}
\hline \multirow[t]{2}{*}{ Political Reasons of National Belonging } & \multicolumn{2}{|c|}{$\begin{array}{l}\text { Turkish } \\
\text { Students }\end{array}$} & \multicolumn{2}{|c|}{$\begin{array}{l}\text { Refugee } \\
\text { Students }\end{array}$} & \multirow{2}{*}{$\begin{array}{l}\text { Dif. } \\
\text { Mean }\end{array}$} & \multirow{2}{*}{$\mathbf{t}$} & \multirow[b]{2}{*}{$\mathbf{p}$} \\
\hline & $\overline{\mathbf{x}}$ & $\mathbf{S}$ & $\overline{\mathbf{x}}$ & $\mathbf{S}$ & & & \\
\hline Being born in this country & 2.75 & .557 & 1.54 & .758 & 1.21 & 19.484 & $.000^{*}$ \\
\hline Being a legal citizen of this country & 2.83 & .436 & 2.15 & .779 & 68 & 10.813 & $.000^{*}$ \\
\hline Being able to exercise the rights I have & 2.67 & .601 & 2.38 & 671 & 29 & 5.297 & $.000^{*}$ \\
\hline An environment of peace & 2.44 & .715 & 2.64 & 608 & 20 & 3.895 & $.000^{*}$ \\
\hline Existence of justice & 2.26 & .778 & 2.50 & .604 & 24 & -.4 .551 & $.000 *$ \\
\hline Trust in the state's institutions & 2.31 & .753 & 2.47 & .700 & 15 & -.2 .506 & $.012 *$ \\
\hline A democratic system of government & 2.34 & .768 & 2.43 & .774 & 09 & 1.484 & .138 \\
\hline Having the same rights with everybody & 2.43 & .753 & 2.36 & .685 & 07 & 1.335 & .183 \\
\hline Being discriminated & 1.88 & .847 & 1.95 & .775 & 07 & 1.085 & .279 \\
\hline Feeling safe & 2.60 & .650 & 2.55 & 622 & 05 & .999 & .318 \\
\hline
\end{tabular}

The three most important political reasons of national belonging for Turkish students were being a legal citizen of this country $(M=2.83)$, being born in this country $(M=2.75)$, and being able to exercise the rights I have $(\mathrm{M}=2.67)$. The first two of these reasons were high enough to make the difference between students statistically significant. For refugee students, the first three political reasons of national belonging were the existence of peace in this country 
$(M=2.64)$, being safe in this country $(M=2.55)$, and the existence of justice in this country $(\mathrm{M}=2.50)$ (Table 12). According to the same table, in terms of an environment of peace, existence of justice, and trust in the state's institutions, refugee students had statistically higher mean scores than Turkish students. One of the striking findings in Table 12 is the sensitivity of both Turkish and refugee students towards discrimination. For both groups, discrimination was determined as the most important issue affecting national belonging negatively. On the other hand, the highest issue that positively affected their national belonging and the agreement level was feeling safe.

Table 13. Independent samples t-test results of Turkish and refugee middle school students' socio-cultural reasons of national belonging

\begin{tabular}{|c|c|c|c|c|c|c|c|}
\hline \multirow{2}{*}{$\begin{array}{l}\text { Socio-Cultural } \\
\text { Belonging }\end{array}$} & \multicolumn{2}{|c|}{$\begin{array}{l}\text { Turkish } \\
\text { Students }\end{array}$} & \multicolumn{2}{|c|}{$\begin{array}{l}\text { Refugee } \\
\text { Students }\end{array}$} & \multirow{2}{*}{$\begin{array}{l}\text { Dif. } \\
\text { Mean }\end{array}$} & \multirow{2}{*}{$\mathbf{t}$} & \multirow[b]{2}{*}{$\mathbf{p}$} \\
\hline & $\overline{\mathbf{x}}$ & $\mathbf{S}$ & $\overline{\mathbf{x}}$ & $\mathbf{S}$ & & & \\
\hline Being able to speak the native language & 2.84 & .447 & 2.28 & .808 & 56 & 8.584 & $.000 *$ \\
\hline $\begin{array}{l}\text { Being able to speak the common language with } \\
\text { the people of this society }\end{array}$ & 2.74 & .536 & 2.45 & .680 & 29 & 5.237 & $.000 *$ \\
\hline Valuing women & 2.34 & .788 & 2.55 & .725 & 21 & 3.365 & $.001 *$ \\
\hline $\begin{array}{l}\text { Having common cultural characteristics with } \\
\text { the people of this country }\end{array}$ & 2.64 & .595 & 2.48 & .644 & 16 & 3.000 & $.003 *$ \\
\hline People respecting differences & 2.39 & .760 & 2.24 & .773 & 15 & 2.299 & $.022 *$ \\
\hline Having relatives living here & 2.37 & .765 & 2.26 & .712 & 11 & 1.914 & .057 \\
\hline $\begin{array}{l}\text { Appreciating the natural beauties of this } \\
\text { country }\end{array}$ & 2.60 & .641 & 2.68 & .599 & 08 & 1.552 & .122 \\
\hline Being able to observe religious beliefs & 2.80 & .498 & 2.77 & .552 & 03 & .665 & .506 \\
\hline Economic conditions & 2.30 & .745 & 2.31 & .718 & 01 & .064 & .321 \\
\hline
\end{tabular}

According to Table 13, the three most important socio-cultural reasons of national belonging for Turkish students' were being able to speak the native language $(\mathrm{M}=2.84)$, being able to observe religious beliefs $(\mathrm{M}=2.80)$, and being able to speak the common language with the people of this society $(\mathrm{M}=2.74)$. For refugee students, being able to observe religious beliefs $(M=2.77)$, appreciating the natural beauties of this country $(M=2.68)$, and valuing women $(\mathrm{M}=2.55)$ were the three most important socio-cultural reasons of national belonging. Among the socio-cultural reasons of national belonging of Turkish and refugee students, arithmetic mean scores of being able to speak the native language, having common cultural characteristics with the people of this country, and people respecting differences were statistically significant in favor of the Turkish students. However, there was a statistically significant difference in Turkish and refugee students' mean scores on valuing women, but in favor of the refugee students. In Table 13, among the socio-cultural reasons of national belonging, being able to observe religious beliefs was a reason for the agreement difference's being at a minimum level for Turkish and refugee students and for both groups's having a high positive view. However, the lowest issue that positively affected their national belonging at a lower level and the agreement level was economic conditions.

Table 14. Independent samples t-test results of Turkish and refugee middle school students' results of national belonging

\begin{tabular}{|c|c|c|c|c|c|c|c|}
\hline \multirow[t]{2}{*}{ Results of National Belonging } & \multicolumn{2}{|c|}{$\begin{array}{l}\text { Turkish } \\
\text { Students }\end{array}$} & \multicolumn{2}{|c|}{$\begin{array}{l}\text { Refugee } \\
\text { Students }\end{array}$} & \multirow{2}{*}{$\begin{array}{l}\text { Dif. } \\
\text { Mean }\end{array}$} & \multirow{2}{*}{$\mathbf{t}$} & \multirow[b]{2}{*}{$\mathbf{p}$} \\
\hline & $\overline{\mathbf{x}}$ & $\mathbf{S}$ & $\overline{\mathbf{x}}$ & $\mathbf{S}$ & & & \\
\hline \multirow{2}{*}{$\begin{array}{l}\text { Being proud of this country's history } \\
\text { Celebrating this country's national holidays } \\
\text { with enthusiasm }\end{array}$} & 2.80 & .470 & 2.56 & .671 & 24 & 4.396 & $.000 *$ \\
\hline & 2.82 & .447 & 2.63 & .679 & 19 & 3.408 & $.001 *$ \\
\hline
\end{tabular}


Listening respectfully to this country's national anthem

$\begin{array}{llllllll}\text { Listening respectfully to this country's } & 2.92 & .320 & 2.77 & .563 & 15 & 3.298 & .001 * \\ \text { national anthem } & & & & & \\ \text { Respecting this country's martyrs } & 2.94 & .264 & 2.82 & .500 & 12 & 3.128 & .002^{*} \\ \text { Valuing this country's flag } & .33 & .301 & 2.82 & .433 & 11 & 3.102 & .002^{*} \\ \text { Making plans regarding the future for this } & 2.38 & .741 & 2.27 & .724 & 11 & 1.715 & .087 \\ \text { country } & 2.15 & .830 & 2.23 & .735 & 08 & 1.200 & .232 \\ \text { Not wanting to live in a different country } & 2.33 & .720 & 2.25 & .744 & 08 & 1.282 & .200 \\ \text { Putting this society before yourself } & 2.74 & .501 & 2.73 & .558 & 01 & .125 & .900 \\ \text { Obeying the rules of this society } & \end{array}$

According to Table 14, the three most important results of national belonging for participating Turkish students' were respecting this country's martyrs $(\mathrm{M}=2.94)$, valuing this country's flag $(\mathrm{M}=2.93)$, and listening respectfully to this country's national anthem $(\mathrm{M}=2.92)$. On the other hand, refugee students referred to martyrs $(\mathrm{M}=2.82)$, flag $(\mathrm{M}=2.82)$, and the Turkish National Anthem $(\mathrm{M}=2.77)$ the most. However, the most important results of national belonging that made a statistically significant difference between Turkish and refugee students were still related to the national values (history, national holidays, national anthem, martyrs, and flag) of this country. The issues that did not create a statistically significant difference between Turkish and refugee students in terms of results of their national belonging were related to their plans for the future, prioritizing this society more than themselves, and their compliance with social rules. However, it is understood from Table 14 that both groups, which reflected their national belonging at a high level in terms of respect for national values, had relatively low willingness to continue their future lives in this country and think about this society before them.

The results of the multiple regression analysis regarding the study variables and political and socio-cultural reasons of national belonging predicting middle school students' result of national are given in Table 15.

Table 15. Multiple regression analysis results regarding the prediction of middle school students' result of national belonging scores

\begin{tabular}{|c|c|c|c|c|c|}
\hline Predictive Variables & B & $\begin{array}{c}\text { Std. } \\
\operatorname{Error}_{B}\end{array}$ & $\boldsymbol{\beta}$ & $\mathbf{t}$ & $\begin{array}{l}\text { Binary } \\
\text { Correlation }\end{array}$ \\
\hline Constant & 13.022 & .503 & & $25.914 * *$ & \\
\hline Political reason & 1.603 & .205 & .249 & $7.804 * *$ & .478 \\
\hline Socio-cultural reason & .272 & .026 & .326 & $10.369 * *$ & .497 \\
\hline School type-public & .453 & .191 & .056 & $2.371 *$ & .060 \\
\hline Legal status-Turkish & .317 & .187 & .041 & 1.694 & .119 \\
\hline $\mathrm{R}^{2}=0.289$ & $\mathrm{~F}_{(4,1308)}=133.059 \mathrm{p}=$ & $=.000$ & & & \\
\hline Constant & 13.161 & .487 & & $27.046 * *$ & $\mathrm{~N}=1317$ \\
\hline Political reason & 1.671 & .202 & .260 & $8.284 * *$ & .480 \\
\hline Socio-cultural reason & .273 & .026 & .326 & $10.415^{* *}$ & .500 \\
\hline School- public & .408 & .189 & .050 & $2.155^{*}$ & .060 \\
\hline $\mathrm{R}^{2}=0.291$ & $\mathrm{~F}_{(3.1314)}=179.820$ & $\mathrm{p}=.000$ & & $\mathrm{~N}=1317$ & \\
\hline
\end{tabular}

According to Table 15, all the models established according to the variance analysis results of regression analysis were significant $(\mathrm{p}<.01)$. In the first model, four variables gave a medium relationship with the result of national belonging scores, and explained $28.9 \%$ of the variance in the scores $(\mathrm{R}=.538, \mathrm{R} 2=0.289)$. In the second model, when the legal status (Turkish) variable was removed from the model, the remaining three variables gave a medium relationship with the result of national belonging scores, explaining $29.1 \%$ of the variance in the result of belonging scores $(\mathrm{R}=.539, \mathrm{R} 2=0.291)$. In the last model, when t-test results 
regarding the standardized regression coefficients $(\beta)$ and the significance of the regression coefficients were examined, it was seen that the strongest and most significant predictor of result of national belonging was socio-cultural reasons, and the second strongest and significant predictor was political reasons $(\mathrm{p}<.05)$. In addition, the school type variable significantly predicted the result of national belonging scores $(\beta=0.050 ; p<0.05)$. According to these findings, it was expected that Turkish students' national belonging scores would be 0.408 higher than refugee students.

According to the regression analysis results, the regression equation (mathematical model) regarding the prediction of students' result of belonging scores is as follows:

Result of Belonging=13.161+1.671 Political+0.273 Socio-cultural+0.408 School type.

\section{Discussion, Conclusion, and Suggestions}

The present study focussed on middle school students' national belonging levels. The analysis of the study data revealed that middle school students' national belonging levels were high in terms of both their political and socio-cultural reasons and the results of their belonging. When this result is assessed in a very shallow and plain way, it may appear positive. However, further elaboration of the data obtained by examining the study variables can give an idea about the contexts in which middle school students' national belonging may develop.

The study found that the gender factor was not effective in middle school students' national identity in terms of both their political and socio-cultural reasons of belonging and the results of their belonging. Although gender is an effective factor in realizing the process of acquiring an identity in a social group that an individual feels belonging to (Alptekin, 2011), it is seen that the spatial belonging of gender difference develops emotionally for women and functionally for men (Şentürk \& Gülersoy, 2019). It is possible to see this in the citizenship perception and practices of gender difference. Nations depict men concretely, as a typical symbol (e.g. soldiers), and women more abstractly with their ideas and ideals (Dilanyan, Doğan, \& Iluridze, 2017). Indeed, women's efforts to achieve political citizenship, e.g. their participation in politics in the context of equality or their access to income equality and social solidarity through social citizenship, can be cited as a reference to gender difference (Lister, 1997 cited in Fenster, 2005). However, the lack of evidence for gender difference in this study may be due to male and female students' adaptation of certain values, both nationally and universally.

The present study put forth that middle school students' national belonging showed a statistically significant difference in terms of political and socio-cultural reasons and results of belonging according to their grade level. This difference was in favor of the 5 th graders among all the other grade levels. However, the very low level of this difference in the study does not require any interpretation of the causality of the difference. Yet, in the research, the effect of grade level on students' national belonging was built on whether Social Studies achieves the targeted learning objectives. Based on the idea that as the grade level increases, Social Studies will contribute more to the students, it is believed that there will be a positive relationship between grade level and national belonging. However, the finding of the present study that students' national belonging scores in 5th grade were higher than other grade levels refutes this thesis. If so, it is necessary to eliminate the effectiveness of the education dimension on students' national belonging and focus on other influential factors. It is possible to see that the belonging of students decreases more in adolescence in terms of grade levels. 
The most important reason for this is to live a stress-free and successful life, which is the most important reason for well-being. However, during adolescence, the feeling of well-being may decrease, which may weaken social relationships. This may negatively affect their belonging (Qutaibaa \& Tamie, 2010).

Another result of the study was that although the school type did not have an effect on the reasons of middle school students' national belonging, there was a significant difference, albeit at a low level, on the results of national belonging in favor of the public schools. Private schools' activities, such as employing qualified teachers, integrating technology into their education, focusing on foreign languages, and strengthening the physical infrastructure of the school, in order to increase the quality of education and have a competitive power, can be a privilege for the students who attend these schools. In addition, the fact that there are students with high socio-economic status in private schools other than scholarship students (Uygun, 2003) creates the perception that these students have high living standards. Therefore, based on the assumption that the socio-economic levels of students attending private education institutions may be higher than public school students, it can be thought that the social status and identities of these students in the society may increase their commitment to the country (Ostrove and Long, 2007). However, the fact that private schools aim to raise individuals who are tolerant towards other cultures and societies while preserving their own cultural and social values (Subaş1 \& Dinler, 2014) can relatively restrain their desire to glorify their own society.

However, in the study, no difference was determined regarding both the political and sociocultural causality of the national belonging of public and private school students. This result suggests that students attending different types of educational institutions may have a similar school culture even if there is a difference in the physical infrastructure, quality of education, or educational characteristics of their schools. Yet, as mentioned before, another result of the study was that the public school students' mean scores regarding the results of national belonging statistically and significantly differed, albeit at a low level, from the mean scores of private school students. This result should be considered natural. The connections with foreign educational institutions and student mobility in private schools in accordance with international education standards, the students' self-confidence in using their foreign language proficiency during their education abroad, as well as the opportunity and desire to continue their higher education and even their profession abroad, may negatively affect their national belonging. As a matter of fact, the mean scores of the answers given by the public school students to the statements of "making future plans for this country" and "not wanting to live in another country" being higher than the mean scores of private school students is a proof of this.

The study also examined whether there was a difference in middle school students' reasons and results of national belonging according to their legal status. Accordingly, the academic mean of Turkish students' scores was statistically and significantly higher than refugee students' scores in terms of both political and socio-economic reasons of national belonging and results of national belonging.

It is possible to examine the study result about Turkish and refugee students' reasons of national belonging in two different dimensions. The first of these is citizenship status, and the second is social interaction. While citizenship status defines individuals' bond with the state within the framework of their rights and responsibilities, it can actually explain this bond as a sign of belonging. Namely, some rights used by individuals within the framework of their citizenship status (voting in elections, working in public institutions) show that their bond 
with the state is strong. Furthermore, individuals know that they cannot be deported due to their citizenship status, and this gives them the feeling of being safe within the borders of the country (Simonsen, 2017). As a matter of fact, in this study, the effect of students' citizenship status on their national belonging was also noticed. The biggest differences in terms of Turkish and refugee students' political belonging emerged in relation to their legal status and their rights, as well as being born in this country. However, the striking point in the study was that spatial belonging was not only effective in terms of strengthening the bond with the state. Today, individuals strengthen their identity not only by having the citizenship identity of the country they were born in, but also by revealing different identity characteristics (ethnic identity, religion, language, and alike) (Özbek \& Engindeniz Şahan, 2016). As a matter of fact, while the concept of citizenship in individuals' minds is systematically taught through education, it can also show an unconscious development influenced by the political and sociocultural environments in which they live (Kesik \& Akbulut Taş, 2020). It is also necessary to mention the importance of social interaction as well as citizenship status. As a matter of fact, belonging is the social interactions of individuals in a group or community to which they feel belonging. Strong social interaction also contributes to social integration. Social integration is a process in which immigrants are not only a part of the host society politically, socially, and economically, but also can protect their own cultural identities (Frideres, 2008 cited in Kitchen, Williams \& Gallina, 2015). During this process, it is highly likely that individuals feel a belonging to the society and state they live in. However, discrimination may occur otherwise. Some studies revealed that the perception of discrimination is an important factor in feeling a low sense of belonging (Carvallo \& Pelham, 2006 \& Hurtado \& Carter, 1997 cited in Liu, Yu, Wang, Zhang \& Ren, 2014). The present study found that some students were exposed to discrimination due to their ethnic origin. As a matter of fact, the arithmetic mean of belonging scores of refugee students regarding not being born in this country, having a different native language and not having common cultural characteristics with the people of this society is statistically and significantly lower than Turkish students' arithmetic mean.

It is also important to address the views of Turkish and refugee students in terms of the results of their national belonging. The existence and continuity of a state are directly related to the belonging of the society's members to the country they live in. The harmony of individuals living in a country with the state and the society is possible by internalizing the national values of that country as well as the universal values. In this study, middle school students' views on national symbols owned by the Turkish nation were evaluated according to their legal status, and the result proved that Turkish students' loyalty to national symbols was statistically and significantly higher than refugee students. When assessed in the context of national culture studies in the literature, this result was not surprising for the researcher. As a matter of fact, national symbols such as history, flag and national anthem of a country that are also among national values are the identity features of that country (Bechhofer \& McCrone, 2012), and the community members of that country do not naturally acquire national values either from birth or while growing up. It is important for individuals to acquire national values by using national symbols in schools. However, the interactive use of national symbols also has a special value. That is to say, the English, French or Danish people do not watch their flags from afar while acquiring their national identity. They wave it by holding it in their hands. They do not only listen to their national anthem, they also sing it (Kolstø, 2006). If so, it may be natural that an individual who has lived in his/her own country since he/she was born and who has spent his/her entire education life in this country has a stronger interest and sensitivity towards national symbols and national values than an individual who immigrated to this country and has recently been involved in the education process. However, it should also be emphasized in this study that although Turkish and refugee students' acquisitions of 
national identity differ, it is their common characteristic that refugee students also make their future plans for this country and do not want to live in another country. This situation may be as a sign of gratitude for this country's opening its doors to them and helping them, and they sometimes stated that there is no other country than this country that may have more common features with them.

In the prediction works of the study, it is seen that the most important factor in the formation of belonging is socio-cultural reasons. Political reasons take the second place. This finding reveals that social interaction is more important than anything else. Namely, the individual prefers the importance and value given to him by real persons to the importance and value given by legal persons/institutions. The reason for this may be that individuals want their identity characteristics to be accepted in the place/society they live in. According to the study results, neither gender nor school type affects middle school students' belonging in terms of socio-cultural reasons. However, their legal status, in other words, whether they are citizens of this country or not is a determining reason for their belonging. It is difficult for individuals who were not born in this country and who cannot share a common language and culture with the people of this society to be accepted by this society. It is also difficult for them to have a strong sense of belonging. In addition to the ethnic discrimination done by the host society, factors such as economic and legal difficulties and unrealized expectations can even be effective in migrating individuals experiencing psychological problems (Bhugra \& Becker, 2005). The study determined that the second important factor in the formation of belonging was political reasons. The citizenship status of individuals indicates a concept of "nation" to which they feel connected based on historical and cultural unity and carry a sense of responsibility (Dağ, 2012). If so, it would be helpful to view citizenship as a national bond rather than a formal identity feature. Some rights brought by the legal status (such as the right to education, the right to choose, or freedom of travel) may be a reason for this result. In addition, refugee students may be more likely to see legal status as a means of social acceptance for them.

In conclusion, individuals' being happy in the country they live in is of great importance in their belonging to the society and the state. One of the most important reasons for this happiness is that their social acceptance in society is at a good level. As a matter of fact, social isolation and exclusion can cause sadness, depression, aggression, and delinquency (MacDonald \& Leary, 2005). Experiencing this in schools will cause students to lack selfconfidence, decrease their academic achievement as well as their commitment to school (Korpershoek, Canrinus, Fokkens-Bruinsma, \& Boer, 2019). Feeling a sense of belonging to the school is directly proportional to feeling a sense of belonging to the society. Considering schools as places that contain a part of the society itself, it is natural to develop a sense of belonging to the society in schools (Akar Vural, Y1lmaz Özelçi, Çengel, \& Gömleksiz, 2013). For this, there are many things to be done in schools in the context of Social Studies. One of them is to include this course outcomes in the content in a way that strengthens the students' sense of belonging. In addition, developing students' social skills will increase their belonging to society and the state. Children's in-class activities, especially using cooperative methods and children's taking individual responsibilities within the group, will increase their self-confidence which is necessary for their social belonging and will ensure that they do not experience the feeling of social exclusion by establishing sincere relationships. It is possible to give the jigsaw technique as an example for such an in-class activity which is useful for Social Studies courses (Neufeld, Matthes, Moulden, Friesen, \& Gaucher, 2016).

However, it is certain that not only our country but all countries of the world have been going 
through a difficult period during the current pandemic process. This difficulty is felt in education as well as in other fields. Although the distance education activities carried out during the pandemic process support students cognitively, not gaining some values, skills and experiences normally acquired through students' interactions in the physical environment affects them negatively in terms of affective aspects. It is difficult for an individual who is away from physical interaction to be aware of or gain awareness of what is happening around him/her. So, in this process, there is a need for digital educational materials that will provide students with awareness cognitively and affectively. Thus, students will be able to have an idea about the processes they could not observe or have experience with, while increasing their knowledge of the subjects. It is not known how long the pandemic process will restrict the opportunity of face-to-face education, but this may affect the national belonging of students in this process. The most important of these issues is the equality of opportunity in education, which is a factor that can be effective in terms of their political belonging. Equality of opportunity in education is the belief that individuals have the right to benefit from educational life and experiences (Kaya, 2002). Distance education activities have the potential to eliminate inequality of opportunity in education. The dissemination of educational activities through information and communication technologies within the framework of the Education Informatics Network (EIN) will ensure that regional differences are minimized. Thus, students from all segments of society will be able to access educational opportunities, and state policies aimed at increasing the quality of education will also positively affect individuals' political belonging. Again, during this process, students' trust or distrust in the health system, acting in accordance with the measures taken within the scope of combating epidemic diseases, may provide different expansions regarding the reasons of their political belonging and the results of their national belonging. What is thought-provoking in this process is how students' socio-cultural belonging will be affected. As mentioned before, social interaction is an important factor in an individual's belonging. "School", which has a very important place in the socialization and acculturation of the individual, provides this importance not only in terms of educational activities but also in terms of social environment and physical space. So, whether or not there will be differences in the sociocultural belongings of the student group who feel valued by their friends and teachers and see this as a positive element for their own belonging, and the student group who think that they are excluded and discriminated by their friends or teachers and therefore believe their belonging is negatively affected is a matter of concern.

\section{References}

Akar-Vural, R., Yılmaz-Özelçi, S., Çengel, M. \& Gömleksiz, M. (2013). The development of the "sense of belonging to school" scale. Eurasian Journal of Educational Research. $53,215-230$.

Allen, K. A. \& Bowles, T. (2012). Belonging as a guiding principle in the education of adolescents. Australian Journal of Educational \& Developmental Psychology, 12, 108-119.

Alptekin, D. (2011). Toplumsal aidiyet ve gençlik: Üniversite gençliğinin aidiyeti üzerine sosyolojik bir araştırma [Social belonging and youth: A sociological research on the belonging of university youth]. Unpublished Doctorate Thesis, Selçuk University, Konya.

Atak, H. (2011). Kimlik gelişimi ve kimlik biçimlenmesi: Kuramsal bir değerlendirme [Identity development and identity formation: A theoretical evaluation]. Current Approaches in Psychiatry, 3 (1), 163-213. 
Bechhofer, F. \& McCrone D. (2012). Imagining the nation: Symbols of national culture in England and Scotland. Ethnicities, 13(5), 544-564. DOI: $10.1177 / 1468796812469501$.

Bhugra, D. \& Becker, M. A. (2005). Migration, cultural bereavement and cultural identity. World Psychiatry, 4 (1), 18-24.

Büyüköztürk, Ş. (2010). Sosyal bilimler için veri analizi el kitabı [Manual of data analysis for social science] (11. Pb.). Ankara: Pegem Publishing.

Carvallo M, \& Pelham B. W. (2006). When fiends become friends: the need to belong and perceptions of personal and group discrimination. Journal of Personality and Social Psychology, 90 (1), 94-108. DOI: 10.1037/0022-3514.90.1.94.

Çağırkan, B. (2019). Çokkültürlü toplumsal yapılarda değișen aidiyet algıları: Yeni toplumlar, yeni aidiyetler [Changing Understanding of the Sense of Belongingness in Multicultural Social Structures: New Societies, New Sense of Belongings]. Hitit University Journal of Social Sciences Institute, 12(2), 558-573. doi: 10.17218/hititsos bil.620067

Dağ, N. (2012). Vatandaşlığın niteliksel dönüşümü ve vatandaşlık eğitimi üzerine bir betimleme çalışması [A descriptive study on the qualitative transformation of citizenship and citizenship education]. Eskişehir Osmangazi University Journal of Social Sciences, 13 (1), 105-118.

Dilanyan, S., Doğan, B. \& Iluridze, A. (2017). Gender and sexuality in the discourses of the nation-state in conflict contexts: Armenia, Georgia, and Turkey. Journal of Conflict Transformation, November, 1-51.

Duru, E. (2015). Genel aidiyet ölçeğinin psikometrik özellikleri: geçerlik ve güvenirlik çalışması [Psychometric properties of general belonging scale: validity and reliability study]. Turkish Psychological Counseling and Guidance Association, 5 (44), 37-47.

Erbaş, H. (2008). Kimlik açmazı: Toplumsal cinsiyet ve aidiyet ya da yabancılaşma duyusu [The identity dilemma: gender and a sense of belonging or alienation]. Ankara University The Journal of The Faculty of Languages and History-Geography, 48 (1), $1-26$.

Fenster, T. (2005). Gender and the city: the different formations of belonging. L. Nelson \& J. Seager (Eds.) in A companion to Feminist Geography (pp. 242-256). USA: Balckwell Publishing. https://www.tau.ac.il/ tobiws/gender_companion.pdf adresinden erişildi.

Gizir, S. (2019). The sense of classroom belonging among pre-service teachers: Testing a theoretical model. European Journal of Educational Research, 8 (1), 87-97. DOI: 10.12973/eu-jer.8.1.87.

Göker, G. (2015). Göç, kimlik, aidiyet, kültürlerarası iletişim açısından İsveçli Türkler [Swedish Turks in terms of immigration, identity, belonging, intercultural communication]. (1. pb.). Konya: LiteraTürk Academia.

Güleç, C. (2002). Türkiye'de kültürel kimlik sorunu [Cultural identity in Turkey]. Ankara University Faculty of Language, History and Geography Journal of Anthropology, 15, 63-78, DOI:10.1501/antro_0000000204.

Hatcher, S. \& Stubbersfield, O. (2013). Sense of belonging and suicide: a systematic review. The Canadian Journal of Psychiatry, 58 (7), 432-436. DOI:10.1177/070674371305800709.

Karasar, N. (1999). Bilimsel araştırma yöntemi [Scientific research method] (9. pb.). Ankara: Nobel Publishing.

Kaya, Z. (2002). Uzaktan eğitim [Distance Education] (1. pb.). Ankara: Pegem Publishing.

Kebede, S. S. (2010). The struggle for belonging: Forming and reforming identities among 1.5- generation asylum seekers and refugees. RSC Working Paper Series, 70, 4-33. 
Kesik, S. \& Akbulut Taş, M. (2020). Ortaokul yedinci sınıf öğrencilerinin vatandaş kavramına ilişkin örtük ve açık bilgilerinin incelenmesi [Examining the implicit and explicit knowledge of the seventh grade students about the concept of citizen]. Education and Science, 45 (203), 91-121. DOI: 10.15390/EB.2020.8559.

Kitchen, P., Williams, A. M. \& Gallina, M. (2015). Sense of belonging to local community is small-to-medium sized Canadian urban areas: a comparison of immigrant and Canadian-born residents. BMC Psychology, 3(28), 1-17. DOI: 10.1186/s40359-0150085-0.

Koç Başaran, Y. (2017). Sosyal Bilimlerde örnekleme kuramı [Sampling theory in Social Sciences]. The Journal of Academic Social Sciences, 5(47), 480-495. DOI: 10.16992/ASOS.12368.

Kolst $\oslash$, P. (2006) National symbols as signs of unity and division. Ethnic and Racial Studies, 29(4), 676-701. DOI: 10.1080/01419870600665409.

Korpershoek, H., Canrinus, E.T., Fokkens-Bruinsma, M. \& de Boer, H. (2020) The relationships between school belonging and students' motivational, social-emotional, behavioural, and academic outcomes in secondary education: a meta-analytic review. Research Papers in Education, 35 (6), 641-680. DOI: 10.1080/02671522.2019.1615116

MEV (National Education Foundation), 2014. Türk Millî Eğitim sisteminin yasal dayanakları [Legal bases of the Turkish National Education system], National Education Foundation.

Liu, D., Yu, X., Wang, Y., Zhang, H. \& Ren, G. (2014). The impact of perception of discrimination and sense of belonging on the loneliness of the children of Chinese migrant workers: a structural equation modeling analysis. International Journal of Mental Health Systems, 8(52), 1-6. DOI: 10.1186/1752-4458-8-52.

MacDonald, G. \& Leary, M. R. (2005). Why does social exclusion hurt? The relationship between social and physical pain. Psychological Bulletin, 131(2), 202-223.

Madsen, K. D. \& Naerssen T. V. (2003). Migration, identity, and belonging. Journal of Borderlands Studies, 18 (1), 61-75. DOI:10.1080/08865655.2003.9695602.

Mavili, A., Kesen, N. F. \& Daşbaş, S. (2014). Aile aidiyeti ölçeği: Bir ölçek geliştirme çalışması [Family belonging scale: A scale development study]. Journal of Social Policy Studies, 14 (33), 29-45. DOI:10.21560/spcd.19507.

Merriam, S. B. (2013). Nitel araştırma, desen ve uygulama için bir rehber [A guide to qualitative research, design and practice]. A guide to qualitative research, design and practice (S. Turan, translate.). Ankara: Nobel Publishing.

Neufeld, K. H., Matthes, K., Moulden, C., Friesen J. P. \& Gaucher, D. (2016). Increasing newcomers' sense of belonging evidence-based strategies from social psychology. Social Sciences and Humanities Research Council of Canada, Retrieved from http://p2pcanada.ca/wp-content/blogs.dir/1/files/2016/07/Increasing-NewcomersSense-of-Belonging.pdf.

Ostrove, J. M. \& Long, S. M. (2007). Social class and belonging: Implications for college adjustment. The Review of Higher Education, 30(4), 363-389. DOI:10.1353/rhe.2007.0028.

Owens, T. J.,Robinson, D. T. \& Lovin, L. S. (2010). Three faces of identity. Annual Review Sociology, 36, 477-499. DOI:10.1146/annurev.soc.34.040507.134725.

Özbek, Ç. \& Engindeniz Şahan, İ. (2016). Yabancı yerleşimcilerin toplumsal aidiyetlerinin yerelde kurulma pratikleri: The Post Gazetesi örneği [The local establishment of social belonging of foreign settlers: The Post Newspaper example]. Süleyman Demirel University Faculty of Arts and Sciences Journal of Social Sciences, 38, 159-182. 
Özyurt, C. (2012). Küreselleşme sürecinde kimlik ve farklılaşma [Identity and differentiation in the globalization process] (2. Pb.), İstanbul: Aç1lım Books.

Qutaibaa, A. \& Tarrieb, R. (2010). Self control and a sense of social belonging as moderators of the link between poor subjective wellbeing and aggression among Arab Palestinian adolescents in Israel. Procedia Social and Behavioral Sciences, 5, 1058-1069.

Seçer, İ. (2018). Psikolojik Test Geliştirme ve Uyarlama Süreci, SPSS ve Lisrel Uygulamaları [Psychological Test Development and Adaptation Process, SPSS and Lisrel Applications] (2. Pb.). Ankara: Anı Publishing.

Simonsen, K. B. (2017). Does citizenship always further immigrants' feeling of belonging to the host nation? A study of policies and public attitudes in 14 Western democracies. Comparative Migration Studies, 5(3), DOI:10.1186/s40878-017-0050-6.

Sözer, M.A. (2019). Göç, toplumsal uyum ve aidiyet [Migration, social cohesion and belonging]. Journal of Bayburt Education Faculty, 14(28), 418-431. DOI:10.35675/befdergi.643948.

Subaşı, B. \& Dinler, A. (2003). Dünyada ve Türkiye"de özel okullar [Private schools in the world and in Turkey], Istanbul Chamber of Commerce, Press Number 2003-21.

Şentürk, A. \& Gülersoy, N. Z (2019). Aidiyet, kent kimliği ve kentsel koruma etkileşimi bağlamında kullanıcı sürekliliğinin irdelenmesi: Kadıköy Moda örneği [Examination of user continuity in the context of belonging, urban identity and urban protection interaction: Kadıköy Moda example]. MEGARON, 14 (1), 145-159. DOI: 10.5505/MEGARON.2018.71676.

Şimşek, S. (2002). Günümüzün kimlik sorunu ve bu sorunun yaşandığ temel çatışma eksenleri [Today's identity problem and the main conflict axes that this problem is experienced]. Uludağ University Faculty of Arts and Sciences Journal of Social Sciences, 3(3), 29-39.

Tekin, H. (1977). Ĕgitimde ölçme ve değgerlendirme [Measurement and Evaluation in Education], Ankara: Mars Publishing.

Uygun, S. (2003). Türkiye'de dünden bugüne özel okullara bir bakış (gelişim ve etkileri) [From yesterday to today, an overview of private schools in Turkey (development and effects)]. Ankara University Journal of Educational Sciences, 36 (1-2), 107-120. DOI: 10.1501/Egifak_0000000083.

Vignoles, V. L (2018). Identity: Personal and social. K. Deaux \& M. Snyder(Eds.) in The Oxford Handbook of Personality and Social Psychology (pp.1-20). New York: Oxford University Press. Retrieved https://www.researchgate.net/publication/316790231_Identity_Personal_AND_Social.

Yıldırım, T. (2014). Tarih ders kitaplarında "öteki” kurgusu: 1930'lı yıllar üzerine bir değerlendirme ["Other" fiction in history textbooks: an assessment of the 1930s]. Turkish History Education Journal, 3 (1), 62-89.

Y1lmaz, V. \& Çelik, H. (2009). LISREL ile yapısal eşitlik modellemesi-I [Structural equation modeling with LISREL-I] (1. pb.). Ankara: Pegem Akademi Yayıncılık.

YUKK, (2021). Yabancilar ve Uluslararas1 Koruma Kanunu- Turkish Foreigners and International Protection Law. Retrieved from https://www.mevzuat.gov.tr/MevzuatMetin/1.5.6458.pdf. 